Dr. Lockhart Robertson's resignation removes a prominent and distinguished personality from the active ranks of our specialty. A slight outline of his past work will, we are assured, be of interest to his fellow associates.

Dr. Robertson's earliest appointment, after a short service as an Assistant Surgeon in the Army, was the post of Assistant Staff-Surgeon to the Military Asylum at Yarmouth, which he held for five years, and during this period assisted the late Dr. Ranking, of Norwich, in preparing his "half-yearly abstract," in which his thorough knowledge of French and German was of great service.

His tenure of office at Yarmouth having expired, he resigned the Army service, entered at Cambridge, graduated as M.B. in 1853, and practised as an alienist physician for four years in London. In I858 he was appointed Medical Superintendent of the Sussex County Asylum, then in course of erection. This post he held until 1870, when he was appointed Lord Chancellor's Visitor.

His management of the Sussex Asylum was distiuguished by marked originality, and soon rendered it one of the institutions to which alienist physicians from other countries paid special attention.

His literary contributions, not ouly to the pages of this Journal, but to the Lancel, British Medical Journal, and the Brighton Mledico-Chirurgical Transections, were numerous and varied, especially bearing on the treatment and modes of care and accommodation of the insane poor. He also translated, in conjunction with Dr. Rutherford, Griesenger's classical work Mental Pathology and Therapentics, published by the New Sydenham Society in 1867.

With the Medico-Psychological Association his connection has been long and intimate. Froin 1855 to 1862 he was General Secretary, and from 1862 to 1870 he edited this Journal in association with Dr. Maudsley. In 1867 he was President, and it will be remembered how ably he presided over the Mental Diseases Section of the International Medical Congress in 1881. Even this number of the Journal contains a record of a valuable presentation of books to our latest departure, the library.

This Association, therefore, is deeply indebted to Dr. Robertson for his past services, and its members must uuanimously unite in the hope that Dr. Robertson's health may be so restored, by relief from his duties, that he may long enjoy his well-earned and honourable rest.

\title{
DR. NICOLSON'S APPOINTMENT.
}

The succession of our highly-esteemed President to the post of Lord Chancellor's Visitor, vacated by Dr. Robertson, will be generally hailed with intense satisfaction. There is always some apprehension that these appointments may be in a measure biased by personal motives. On the present occasion there can be no doubt that intrinsic merit has decided the question, and we can, therefore, heartily congratulate Dr. Nicolson on the promotion which has resulted from his long and able services at Broadmoor, and the distinguished ability that he has 80 often manifested.

\section{PRESENTATION TO SIR ARTHUR MITCHELL.}

On the 24th of Jannary last, in the library of the Society of Antiquaries, Queen Street, Edinburgh, Sir Arthur Mitchell was presented with his portrait, along with other gifts to Lady Mitchell and himself, on the occasion of his retirement from the General Board of Lunacy. Lord Kinnear occupied the chair, and there was a large and representative gathering of Sir Arthur's friends.

After reading letters of apology for absence, Dr. Robert Munzo, Hon. Secretary of the Committee, read a report recalling the steps which had led up to the present gathering. It mentioned that at a meeting held in December, 1894, under the presidency of Sir Douglas Maclagan, it was agreed that the occasion of Sir Arthur Mitchell's retirement from the Lunacy Board was a fitting opportunity of testifying in some tangible form the respect and regard entertained for him 
during his loug career of public usefulness. A Ccmmittee was appointed, consisting of Lord Kinnear, Mr J. R. Findlay, Dr. Clouston, and Dr. John Murray, with Dr. Robert Munro as Hon. Secretary, and in response to a circular $£ 765$ was raised. The Committee commissioned Sir George Reid, P.R.S.A., to paint Bir Arthur's portrait, and Mr. James Faed was also commissioned to execute a mezzotint of the portrait to be presented to each of the 256 subscribers. It was agreed by the Committee to hand 50 guineas to Lady Mitchell to purchase an ornament as a souvenir of the occasion, and to hand over the balance to Sir Arthur for the purchase of books to be added to his library.

Lord KINNEA a then rose to make the presentation. He said he thought it a very great honour to be invited to convey to Sir Arthar Mitchell the sentiments which so many of his friends and 80 many of his professional brethren desired that he should take with him on his retirement from public office some memorial of their great esteem and regard. He was sure it would be agreeable to Sir $\Delta r t h u r$, and, for many reasons, it would be becoming, that be should do so without any kind of preface and in the fewest possible words. They were there to express their personal regard and respect, and these were feelings which they were the least willing to talk about the more sincerely they were felt. He thought he had said enough when he had used these words; but they were there also to express to Sir Arthur Mitchell the gratitude which was due to him for great and memorable public service. That was a topic upon which he had not sufficient knowledge to speak. He had hoped that in the statement which Dr. Munro had just read to them he might have included the views of the profession, which was the best judge, and, indeed, the only competent judge, of the services of Sir Arthur Mitchell in the administration of lunacy. He was fortunate, however, in being able to speak with higher authority than his own, because at the meeting to which Dr. Munro had referred no one could avoid being struck with the extreme unanimity with which the leading members of Sir Arthur Mitchell's profession rose one after another to give their own tribute, and the tribute of those who were unable to be present-the tribute of their professional brethren in all parts of the country - to the services of Sir Arthur Mitchell. And then there was a most admirable and most interesting paper on the administration of lunacy in Scotland, which he wished everybody would read, contributed by Dr. Clouston to an American magazine-a paper which contained such a tribute to the administration of a public body as he very much doubted whether they would find equalled in that kind of literature. He was only repeating Dr. Clouston's words when he said that during the five-and-thirty years, he was afraid, or nearly that, in which Sir Arthur Mitchell had been a member of the Lunacy Board-from the rery commencement of the labours of that body-the policy of the Board had throughout been wise and liberal ; that it considered from the first the peculiar wants of the country and the peculiar necessities with which it had to deal; that it had done much to advance medical science, much to enlighten the affictions of the insane, and much to satisfy the just demands of that brauch of the profession which was engaged in the management and treatment of the insane; that it had educated public opinior; that it had obtained the confidence of the country; and that in all its dealings with all classes of men with whom it had been brought into contact it had been just, fearless, and generous, so as to earn the gratitude of all persons engaged in the great work the administration of which it controlled, from the great physicians and managers of the leading asylums of this country down to the humblest Inspector of Poor in the smallest country parish. They vere not all in the position to have ascertained for themselves the truth of these statements, but he thought they were at least able to value the eulogy of such a man as Dr. Clouston, and they were able to appreciate the great and admirable qualities which must have been combined to enable the Board of Lunacy and its medical members to carry through so anxious and so vast a system of administration for so long a time, and to earn at the end of five-and-thirty years the admiration, the regard, and the respect of the medical community. He was sure it must be an immense gratification to Sir Arthur Mitchell to know that he retired from public service leaving behind him no resentments, no unpleasant memories, 
no harsh recollections, but with the cordial goodwill and esteem of a great profession, and the affectionate respect of many of its members. But Sir Arthur had not allowed himself to be absorbed even in so exacting a pursuit as that which had formed the business of his life. He had had time to give to letters, to history, to archøology - they had all read the delightful book which had gained him so high a reputation on that subject-and to public business of other kinds, and he (Lord Kinnear) had during the last few years great opportunities of seeing the admirable tact and judgment and good sense and kindly feeling which Sir Arthur brought to the solution even of troublesome and vexatious problems. Sir Arthur had also, happily for all of them, found time to give to society and to friendship. In conclusion he had to request Sir Arthur Mitchell to accept the portrait just unveiled as a tribute of the great respect and esteem of many friends and many professional brethren, and to tell him at the same time how much they were gratified by Lady Mitchell's having been pleased to accept also some memorial of the esteem in which her husband was held by his brethren. He had only further to express their most sincere wishes for his welfare and happiness in the leisure which they knew would be fruitful, and to hope that this portrait might for many years remain to him, and to those who were nearest to him, as a token of their regard and respect, and that afterwards it might preserve for generations who were to come after him the memory and the likeness of a very perfect, gentle knight.

Sir Arthor M I tch kLI-Lord Kinnear, Ladies and Gentlemen, - Even persous of ready speech sometimes find it difficult to say what they would like to say. But ready speech is not mine at any time, and just now I know that words must fail me when I try to " deliver the message of my heart." You have presented to me a princely gift from a crowd of friends, and "I can no other answer make but thanks and thanks,"-thanks unspeakable. My first feeling is one of gratitnde for such a tokeu of esteem. If there is pride in my thankfulness, it is not the pride which would make the mixed feeling a base alloy. I am proud of what my friends have done. It gives me inexpressible pleasure. But the pride and pleasure are not rooted in any sense of worthiness. The gift comes to me "without deservingness ;" and the sense of this has been deepened by the good things which you, Lord Kinnear, in presenting it, have so pleasantly and gracefully said of me-in "words of so sweet breath" as greatly to eurich the gift. This act of kindness has made me realise how much $I$ am a debtor all round-all along the road of my life, down to the present hour. My years, which are now many, have been filled with hard, earnest work. I have loved that work; my soul was in it; I think it had some success; and it gires me pleasure to remember how abundantly I have been helped. I look back on a life which has been full of happiness. Truuble and sorrow have come my way, but happiness has reigned. I have found the world comely, and the name of the helping friends I have met in it is legion. To them I am deeply a debtor. By this day's doings, how greatly is my debt increased I I have spoken of the work of my life, and, in doing so, I have had special reference to that work which was connected with Lunacy Administration in Scotland, England, and Ireland, but particularly, of course, in Scotland. This has been the work of my life; but, to my own advantage, I believe, and to $\mathrm{my}$ enjoyment certainly, I have had an active interest in other lines of work-for example, in archæology and meteorology. When that interest first arose, I intended it to result only in relaxation or play, but it came soon to be a play which was pleasantly laborious. It is of my lunacy work, however, that I desire now chiefly to speak. In that work I have had the good fortune to be constantly associated with very distinguished colleagues, and I count them all as close and fast personal friends. Of the colleagues with whom I began my lunacy work not one remains. "They have all gone into the world of light." This is neither time nor place to say more of what Lunacy Administration owes to them than that it is incalculable. Very pleasant they were to me, and their influence and example have done much to shape my life. But I have had the further good fortune in my lunacy work to be in direct and close official relations with a body of enlightened, earnest men, actuated by the very aims which actuated myself, and from whom I was constantly learning. I refer to the Medical Superin- 
tendents of the Asylums of Scotland. Among the physicians of the world who are devoted to the care and treatment of the insane many of these gentlemen stand in the very front rank. I have regarded them all as personal friends. This day of days makes memory do "her wonted work," and with tender regret I call to mind those of them "who have fallen on sleep." In the conditions described, it was easy to succeed and be happy. It was not necessary that we, either they or I, should lose the courage of our opinions. We were co-operating -had the same objects at heart; and "the power which forms opinion" fused our differences, and led to agreement about the right way, which many times was not the way by which I had desired to trarel. But not with Superintendents of Asylums only, as enlightened and right-hearted men, have I had pleasant and profitable official relations. The bodies of men who direct establishments for the insane, though sometimes opposing the views which 1 advocated, have yielded me au army of helping friends; and I have drawn them largely also from those concerned in the management of the insane poor who are not in establishments. I say nothing of the insane themselves, except that I know that all of them have had a fast and warm friend in me, and that I believe many of them were able to realise this. To add to their happiness-to improve their well-being-has been the underlying aim of all my work. I have thought it proper to speak first and chiefly of the friendship and happiness that were born of my official relations as a Commissioner in Lunacy ; but my other work, which has gone in many directions, has brought me a bost of true and helpful friends, many now gone-with grief I say it-but many yet alive. How much I prize these friendships, and the many other friendships not arising out of work of any kind-how much pleasure they have brought, and still bring, into my life my tougue cannot tell. Friendship is called "the wine of life," and with thankfulness I feel to-day that I have been privileged to drink freely of that wine. It has brought me a "solid happiness," and so has helped me on, by giving me whole dajs for my work, instead of the half days of the unhappy. My official work is now ended. As regards it I have reached old age. But I am not yet conscious of decrepitude, and certainly not of a sad old age. I hope that there is some work still in me, and I mean to do it, though I may to some extent "coil the ropes and take the canvas in." I once thought that I should like to have it said of me, when the very end had comeHe "lay dead in his harness ;" but I am pleased now to feel that I belong to the leisured class, and that I am free to work or to play as I choose. For such work as I have done I have had rich acknowledgments, both from Academies and from the State, and, crowning all, comes the acknowledgment of friendship which I receive to-day. It is "beyond my speaking" to show in words the measure of my gratitude for all the good that has befallen me. Of the portrait, a splendid work of art, I say nothing except that for its flattery I am again a debtor to friendship-to the friendship of the distinguished painter. I am glad that I shall be remembered as I was seen by him, and also by that man of skill from whose hands the engraving comes. I have had to speak of gifts and not of a gift. In addition to the portrait there is a handsome gift to $\mathrm{ms}$ wife. I cannot tell how much this remembrance of her has gratified us both. She begs me to say that no greater pleasure has ever reached her, and that the kindness to us both has filled her heart with sweetness to the core. The gift to her will take such a shape as will be a perpetual reminder to her of my friends, or rather, as she desires to put it, of $\mathrm{my}$ friends and hers. There is a further gift of books to me. Books of value they shall be-books to which, during the days of my life that remain, I shall be always making reference, and from which I shall be constantly drawing enjoyment. Thus in rarious ways the memory of this day will be kept green in my heart and home.

[We have much pleasure in having secured a photograrure of the mezzotint by Mr. Faed, as inserted in this number of the Journal, and re-echo the kindly wishes of Lord Kinnear for Sir Arthur Mitchell's welfare and happiness.-ED.] 